\title{
TINJAUAN MEDIKOLEGAL PERKIRAAN SAAT KEMATIAN
}

\author{
${ }^{1}$ Eklesia A. Senduk \\ ${ }^{2}$ Johannis F. Mallo \\ ${ }^{2}$ Djemi Ch. Tomuka
}

\author{
${ }^{1}$ Kandidat Skripsi Fakultas Kedokteran Universitas Sam Ratulangi Manado \\ ${ }^{2}$ Bagian Ilmu Kedokteran Forensik Fakultas Kedokteran Universitas Sam Ratulangi Manado \\ Email: eklesia.senduk@yahoo.com
}

\begin{abstract}
Most human beings will experience cycles of life, including the processes of natural conception, birth, and death. From the various life cycles mentioned, death is the one that still contains a huge mystery. Death also affects the close relatives and others connected to the deceased. Death is not only a medical and social issue, but also an important legal issue. In homicide cases, the estimated time of death can help reveal the identity of the murderer, and as a clue to the whereabouts of the crime scene. A certification of death made by a medical doctor will help the deceased's relatives to claim insurance, legally change his/her marriage status, and other legal interests. It is every medical doctor's concern to master the basics of estimating post mortem intervals.
\end{abstract}

Keywords: post mortem interval, death

\begin{abstract}
Abstrak: Semua makhluk hidup termasuk manusia akan mengalami siklus kehidupan, berawal dari proses pembuahan, kelahiran, kehidupan didunia, dan diakhiri dengan kematian. Dengan kata lain semua manusia sudah didiagnosis untuk mati. Kematian tidak hanya akan mempengaruhi almarhum/almarhumah saja, namun juga keluarga maupun orang-orang yang terhubung dengan almarhum/almarhumah. Kematian bukan hanya masalah medis dan sosial, namun juga merupakan masalah hukum yang teramat penting. Perkiraan saat kematian akan membantu penyidik untuk membuka identitas pembunuh, dan memberi petunjuk mengenai dimana sebenarnya tempat kejadian perkara. Sertifikasi kematian oleh dokter juga akan membantu keluarga almarhum untuk memperoleh hak hukumnya, seperti asuransi, perubahan status perkawinan dan kepentingan hukum lainnya. Pemahaman dasar-dasar perkiraan saat kematian menjadi kepentingan setiap dokter dalam melaksanakan tugasnya.
\end{abstract}

Kata kunci: mati, perkiraan saat kematian.

Perkiraan saat kematian pada kematian yang bukan akibat kejahatan hampir selalu tidak merupakan masalah penting. Umumnya hal ini hanya untuk kepentingan keluarga dan kepentingan sejarah.

Dalam kasus kematian yang merupakan kejahatan, perkiraan saat kematian yang mendekati saat kejadian atau kematian sangat penting, khususnya bila dikaitkan dengan proses penyidikan; dengan demikian penyidik dapat lebih terarah dan selektif dalam melakukan pemeriksaan terhadap para tersangka pelaku tindak pidana. Benar tidaknya alibi seseorang yang diduga mempunyai hubungan dengan sebab kematian korban dapat diketahui dari perkiraan sebab kematian.

Semua makhluk hidup termasuk manusia mengalami siklus kehidupan, yaitu berawal dari proses pembuahan, kelahiran, kehidupan didunia, dan diakhiri dengan kematian. Kematian dianggap sebagai peristiwa luar biasa yang membatasi kehidupan manusia, dan dapat berpengaruh 
besar terhadap individu tersebut. Dari berbagai siklus kehidupan di atas, kematian merupakan salah satu yang masih mengandung misteri yang sangat besar. ${ }^{1}$

Untuk dapat memperkirakan saat kematian perlu diketahui perubahanperubahan yang terjadi pada tubuh seseorang yang meninggal dunia (jenazah), dan juga faktor-faktor yang turut berperan dalam terjadinya perubahan tersebut. Mati merupakan masalah yang sudah pasti terjadi pada setiap mahluk hidup, tetapi saat terjadinya tidak pernah diketahui dengan tepat. $^{2}$

Pengertian tentang kematian itu sendiri mengalami perkembangan dari waktu ke waktu sejalan dengan perkembangan ilmu pengetahuan dan penggunaan alat-alat yang mutakhir.

Kematian dapat dibagi menjadi dua fase, yaitu: somatic death (kematian somatik) dan biological death (kematian biologik). Kematian somatik merupakan fase kematian dimana tidak didapati tandatanda kehidupan lagi, seperti denyut jantung dan gerakan pernapasan, suhu badan menurun, dan tidak adanya aktivitas listrik otak pada rekaman EEG. Setelah dua jam, kematian somatik akan diikuti kematian biologik yang ditandai dengan kematian sel. $^{2}$

Dengan adanya kemajuan ilmu pengetahuan seperti penggunaan alat respirator (alat bantu nafas), seorang yang dikatakan mati batang otak (yang ditandai dengan rekaman EEG yang datar) masih bisa menunjukkan aktivitas denyut jantung, suhu badan yang hangat, dan berfungsinya alat-alat tubuh lainnya (sebagai contoh: ginjal) selama terdapat bantuan alat respirator tersebut. Bila alat respirator dihentikan, maka dalam beberapa menit akan muncul tanda kematian somatik lainnya. Hal-hal demikian menyebabkan terjadinya kesulitan dan ketidakseragaman penentuan terjadinya kematian. ${ }^{1}$

\section{BATASAN DARI 'KEMATIAN'}

Dengan perkembangan ilmu pengetahuan maka definisi kematian berubah mengikuti ilmu pengetahuan yang berlaku. Umumnya, mati dapat didefinisikan secara sederhana sebagai berikut: berhentinya tiga penunjang kehidupan yaitu sistem saraf pusat, jantung, dan pernapasan secara permanen, yang disebut sebagai mati klinis atau mati somatik. ${ }^{2}$

Pernyataan IDI tentang mati mencakup hal-hal sebagai berikut: ${ }^{1}$

1. Mati adalah suatu proses yang berangsur-angsur. Tiap sel dalam tubuh manusia mempunyai daya tahan yang berbeda-beda terhadap tidak adanya oksigen dan oleh karenanya mempunyai saat kematian yang berbeda pula.

2. Bagi dokter, kepentingan bukan terletak pada tiap butir sel tersebut, tetapi pada kepentingan manusia itu sebagai suatu kesatuan yang utuh.

3. Dalam tubuh manusia ada tiga organ tubuh yang penting yang selalu dilihat dalam penentuan kematian seseorang, yaitu jantung, paru-paru, dan otak (khususnya batang otak).

4. Di antara ketiga organ tersebut, kerusakan permanen pada batang otak merupakan tanda bahwa manusia itu secara keseluruhan tidak dapat dinyatakan hidup lagi.

5. Oleh karena itu, setelah mendengar pertimbangan dari para ahli kedokteran, agama, hukum, dan sosiologi, IDI berpendapat bahwa manusia dinyatakan mati jika batang otak tidak berfungsi lagi.

6. Sadar bahwa pernyataan tentang kematian ini akan mempunyai implikasi teknis dilapangan, dengan ini IDI mengajukan usulan perubahan terhadap PP No. 18, tahun 1981, terutama yang berkenaan dengan definisi mati seperti yang tercantum dalam pasal 1 ayat $\mathrm{g}$ dari peraturan tersebut.

7. Perlu diingatkan sekali lagi kepada setiap dokter bahwa pada dasarnya tugas dokter adalah untuk mengurangi penderitaan pasien dan jika mungkin menyembuhkan kembali secara sempurna dan bertindak demi kepentingan pasien tersebut. Meskipun dokter 
menghadapi penyakit-penyakit yang belum dapat disembuhkan atau adanya cacat yang tidak dapat dipulihkan, dokter tetap harus bertindak demi kebaikan pasiennya, sampai saat pasiennya dapat kembali ke keluarganya atau dinyatakan mati.

Tanatologi merupakan bagian dari Ilmu Kedokteran Forensik yang mempelajari kematian dan perubahan yang terjadi setelah kematian serta faktor-faktor yang mempengaruhi perubahan tersebut. Seorang dokter tidak jarang menemui kesulitan untuk mendiagnosis apakah pada seseorang sudah terjadi kematian atau belum., ${ }^{1,2}$

Tanatologi berasal dari kata thanatos (yang berhubungan dengan kematian) dan logos (ilmu). Dalam tanatologi dikenal beberapa istilah tentang mati, yaitu mati somatik (mati klinis), mati suri, mati seluler, mati serebral dan mati otak (mati batang otak). ${ }^{1,2}$

Mati somatik (mati klinis) terjadi akibat terhentinya fungsi ketiga sistem penunjang kehidupan, yaitu susunan saraf pusat, sistem kardiovaskuler dan sistem pernapasan yang menetap. Secara klinis tidak ditemukannya refleks-refleks, EEG mendatar, nadi tak teraba, denyut jantung tidak terdengar, tidak ada gerak pernapasan, dan suara pernapasan tidak terdengar pada auskultasi.

Pada mati batang otak, telah terjadi kerusakan seluruh isi neuronal intra-kranial yang ireversibel, termasuk batang otak dan serebelum. Dengan diketahuinya mati otak atau batang otak maka dapat dikatakan seseorang secara keseluruhan tidak dapat dinyatakan hidup lagi, sehingga alat bantu dapat dihentikan.

Mati suri (mati semu) yaitu terhentinya tiga sistem kehidupan (susunan saraf pusat, sistem kardiovaskuler, sistem pernapasan) yang ditentukan dengan alat kedokteran sederhana. Dengan peralatan kedokteran yang canggih masih dapat dibuktikan ketiga sistem tersebut masih berfungsi. Mati suri sering ditemukan pada kasus keracunan obat tidur, tersengat aliran listrik, dan tenggelam.

Mati seluler (mati molekuler) merupakan kematian organ atau jaringan tubuh yang timbul beberapa saat setelah kematian somatik.

Pada mati serebral, kerusakan kedua hemisfer otak yang ireversibel kecuali batang otak dan serebelum, sedangkan kedua sistem lainnya yaitu sistem pernapasan dan kardiovaskular masih berfungsi dengan bantuan alat. ${ }^{1,2}$

\section{BAHASAN}

Kematian pada saat ini tidak hanya merupakan masalah di dalam kedokteran saja, akan tetapi juga mempunyai aspek legal. Seseorang dinyatakan mati baik dilihat dari kedokteran maupun dari segi hukum bila dokter atas dasar pengetahuan kedokteran yang sesuai dengan standar profesi tidak lagi menemukan adanya tanda kehidupan yang spontan. Konsep mati dan berhentinya darah mengalir seperti dianut selama ini dan juga diatur dalam PP. 18 thun 1981 yang menyatakan bahwa mati adalah berhentinya fungsi jantung, paruparu, tidak bisa diperguna-kan. Hal ini disebabkan karena teknologi resusitasi telah memungkinan jantung dapat dipacu untuk berdenyut kembali dan paru-paru dapat dipompa untuk kembang-kempis kembali. ${ }^{3}$

Walaupun tanda-tanda kematian somatik sudah tampak, sebelum terjadi kematian biologik masih dapat dilakukan berbagai macam tindakan seperti pemindahan organ tubuh untuk transplantasi, kultur sel, jaringan dan organ atau jaringan tubuh individu tersebut masih dapat dipertahankan hidup terus walaupun berada pada tempat yang berbeda selama mendapat perawatan yang memadai.

Kecenderungan dunia kedokteran pada saat ini menempatkan otak (dalam hal ini batang otak) sebagai kriteria yang paling menentukan dalam hal memastikan adanya kematian seseorang, sebagaimana kriteria yang diajukan oleh Harvard Medical School, dimana salah satu tes yang terpenting ialah pemeriksaan aktivitas otak 
dengan elektroensefalograf $(\mathrm{EEG}){ }^{2,4}$ Dengan demikian seseorang akan dinyatakan mati bila pada pemeriksaan tidak ditemukan adanya aktivitas otak yang tampak dari hasil pemeriksaan EEG yang mendatar. Pendapat lain mengatakan bahwa tidak pada tempatnya jika dokter memutuskan bahwa seorang telah mati walaupun EEG telah membuktikan hal tersebut, tetapi masih terlihat adanya pernapasan spontan. Penentuan kematian tersebut amat penting artinya bila dikaitkan dengan kemungkinan untuk dilakukannya tindakan transplantasi. ${ }^{4}$

Dengan demikian makin sulit seorang ilmuwan medis menentukan terjadinya kematian pada manusia, apakah kematian somatik secara lengkap harus terlihat sebagai tanda penentu adanya kematian, atau cukup bila didapati salah satu dari tanda kematian somatik, seperti kematian batang otak saja, henti nafas saja, atau henti detak jantung saja sudah dapat dipakai sebagai patokan penentuan kematian manusia. Permasalahan penentuan kematian ini sangat penting dalam pengambilan keputusan baik oleh dokter maupun keluarganya.

Dalam peraturan perundang-undangan di Indonesia, batasan mati telah diangkat dalam peraturan pemerintah yaitu pada PP no. 18 Tahun 1981 tentang Bedah Mayat Klinik dan Bedah Mayat Anatomis serta transplantasi alat dan/atau jaringan tubuh manusia. Pada Bab 1 Pasal 1 tentang Ketentuan Umum Ayat g, dijelaskan bahwa "Meninggal dunia adalah insani yang diyakini oleh ahli kedokteran yang berwenang bahwa fungsi otak, pernapasan dan atau denyut jantung seseorang telah berhenti". Ayat g diatas mengenai definisi meninggal dunia kurang jelas; oleh karena itu IDI dalam seminar nasionalnya telah mencetuskan fatwa tentang masalah mati yang dituangkan dalam SK PB IDI No. 336/PB IDI/a.4 tertanggal 15 Maret 1988 yang disusul dengan SK PB IDI No. 231/PB.A.4/07/90. Dalam fatwa tersebut dinyatakan bahwa seseorang dinyatakan mati bila fungsi spontan pernafasan dan jantung telah berhenti secara pasti atau ireversibel, atau bukti telah terjadi kematian batang otak. ${ }^{4}$
Hukum tidak memberikan rumusan yang tegas mengenai kematian seseorang, dan hanya menyebutkan bahwa kematian adalah hilangnya nyawa seseorang tanpa penjelasan lebih lanjut. Kenyataannya, dengan kemajuan ilmu pengetahuan dan teknologi (iptek) kedokteran masa kini detak jantung dan napas seseorang dapat terus dipertahankan karena fungsi otonomnya dengan bantuan alat medis tertentu walaupun sebenarnya otak atau batang otak telah berhenti berfungsi. ${ }^{1}$

Dengan adanya alat respirator maka disusunlah kriteria diagnostik baru untuk kematian yang berdasarkan konsep brain death is death. Kemudian dengan ber-bagai dasar pemikiran, konsep ini diperbaharui menjadi brain stem death is death. Dunia cenderung menempatkan otak sebagai kriteria yang paling menentukan untuk memastikan adanya kematian pada seseorang melalui pemeriksaan aktivitas otak dengan elektroensefalograf (EEG). Seseorang akan dinyatakan mati bila pada pemeriksaan tidak ditemukan adanya aktivitas otak sebagaimana dilihat dari hasil pemeriksaan EEG yang mendatar. Tetapi masih ada yang berpendapat tidak pada tempatnya diputuskan mati walaupun EEG telah membuktikan hal tersebut, karena masih terlihat adanya pernapasan. Adanya perubahan-perubahan yang terjadi setelah kematian, yang menurut kenyataannya memiliki pola tertentu, memungkinkan untuk dapat memperkirakan kematian seseorang. ${ }^{2}$

\section{SIMPULAN}

Kematian merupakan suatu keadaan yang tidak dapat dihindari oleh manusia. Seseorang dinyatakan mati baik dilihat dari segi kedokteran maupun dari segi hukum bila dokter atas dasar pengetahuan kedokteran yang sesuai dengan standar profesi tidak lagi menemukan adanya tanda kehidupan spontan, yang ditandai oleh tidak berfungsinya batang otak dan telah terhentinya peredaran darah dan pernapasan.

\section{DAFTAR PUSTAKA}

1. Idries AM, editor. Saat Kematian. In: 
Pedoman Ilmu Kedokteran Forensik. Jakarta: Bina Rupa Aksara, 1997; p.5383.

2. Atmadja DS. Thanatologi. Ilmu Kedokteran Forensik. Jakarta: Balai Penerbit FKUI, 1997; p.25-36.

3. Sampurna B, Samsu Z, Siswaja TD. Peranan Ilmu Kedokteran Forensik dalam Penegakan Hukum; Sebuah Pengantar. Jakarta: Bagian Kedokteran
Forensik FKUI; 2008.

4. Hanafiah MJ, Amir A. Etika Kedokteran dan Hukum Kesehatan (Edisi 3). Jakarta: Penerbit Buku ECG, 1999; p. 104-9.

5. Idries AM, Tjiptomartono AL. Penerapan Ilmu Kedokteran Forensik dalam proses Penyidikan (Cetakan 1, Edisi Revisi). Jakarta: Sagung Seto; 2008. 